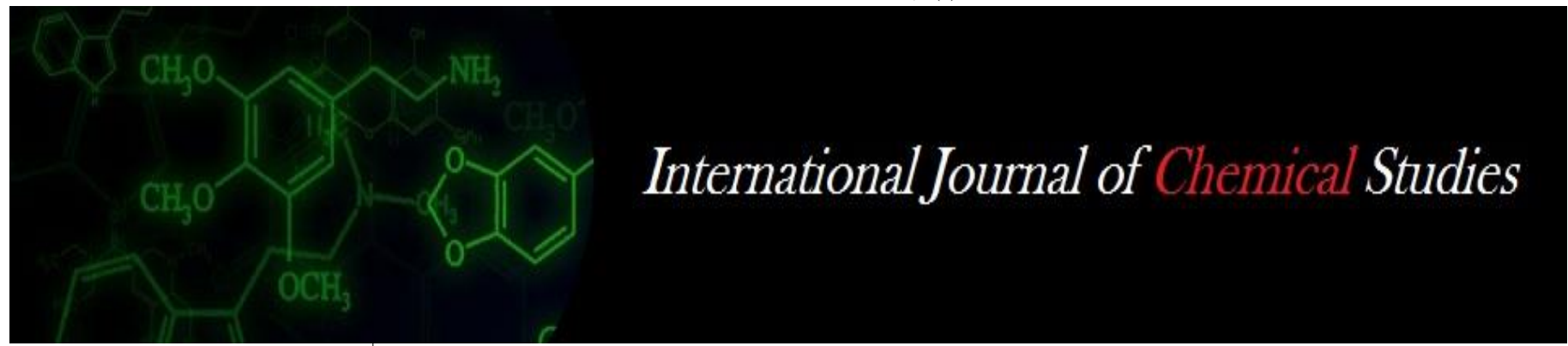

P-ISSN: 2349-8528

E-ISSN: 2321-4902

www.chemijournal.com

IJCS 2021; 9(1): 2872-2876

(C) 2021 IJCS

Received: 08-10-2020

Accepted: 17-12-2020

Yugandhar G

College of Horticulture,

Rajendranagar, SKLTSHU,

Telangana, India

\section{Bhagwan A}

College of Horticulture,

Rajendranagar, SKLTSHU,

Telangana, India

Kiran Kumar A

College of Horticulture,

Rajendranagar, SKLTSHU,

Telangana, India

\section{Cheena J}

College of Horticulture,

Rajendranagar, SKLTSHU,

Telangana, India

Corresponding Author:

Yugandhar G

College of Horticulture,

Rajendranagar, SKLTSHU,

Telangana, India

\section{Different bio-chemical changes at low temperature storage on chilling injury and storage life of commercial cultivars of mango Mangifera indica $\mathbf{L}$.}

\author{
Yugandhar G, Bhagwan A, Kiran Kumar A and Cheena J
}

DOI: https://doi.org/10.22271/chemi.2021.v9.i1an.11668

\begin{abstract}
An experiment was conducted at Fruit Research Station, Sangareddy, Medak, Telangana to study the effect of low temperature storage on chilling injury and storage life of different commercial cultivars of mango (Mangifera indica L.) viz., Banganpalli, Dashehari, Peddarasam, Chinnarasam and Totapari stored at $8^{\circ} \mathrm{C} \pm 1^{\circ} \mathrm{C}$. The experimental design followed is completely randomized design with factorial concept with four replications per treatment.Various biochemical parameters like TSS, titratable acidity, ascorbic acid, reducing sugars, non reducing sugars and electrolyte leakage. The highest T.S.S. (15.35) was recorded in mango cv. Peddarasam, Among all interactions, the highest TSS (16.75) was recorded on $55^{\text {th }}$ day with the mango cv. Peddarasam. The lowest acidity (0.70) was recorded in mango cv. Chinnarasam and the highest acidity (1.00) was recorded in cv. Totapari. The lowest brix acid ratio (10.04) was noticed in mango cv. Totapari. The highest (23.53) was recorded in mango cv. Peddarasam. The treated fruits were significantly influenced by low temperature with lowest reducing sugars (2.11) recorded in mango cv. Totapari. The highest total sugars (6.51) were recorded in mango cv. Peddarasam. The lowest total sugars (4.40) were recorded in mango cv. Totapari. The treated fruits differed significantly with highest vitamin-C (17.07) was recorded in mango cv Peddarasam while the lowest vitamin-C (9.67) recorded in mango cv. Banganpalli. The treated fruits differed significantly with lowest electrolyte leakage (13.85) recorded in mango cv. Totapari.
\end{abstract}

Keywords: Ascorbic acid, electrolyte leakage, non reducing sugars, reducing sugars, TSS and titratable acidity

\section{Introduction}

Mango (Mangifera indica L.) is one of the most popular fruits and commonly known as 'King of fruits' in Asian countries. Because of its delicious taste and pleasant flavour, it is ranked as one of the choicest fruits in the National and International market. Mango is a climacteric fruit and hence, ripe and deteriorate very fast when stored at ambient temperature, which leads to reduction in shelf life. Its each part like pulp, peel, seed, leaves, flowers and the bark are important due to their medicinal uses. Different part of mango contains many biotic compounds like polyphenolics which can control many degenerative diseases due to their antioxidant activities. Hence, it is gaining more importance in medicinal and pharmaceutical industries. Therefore, low-temperature storage is necessary to slow down the metabolic processes and decay development but, when this fruit is stored at temperature below $13{ }^{\circ} \mathrm{C}$, it develops chilling injury (CI) which further limits its shelf life during low-temperature storage and subsequently lead to rapid spoilage. The chilling injury symptoms in mango manifest as discoloration and pitting of the peel, sunken lesions, lenticels spotting, shriveling, uneven ripening, poor colour, off-flavour development and increased susceptibility to decay resulting in the reduction of market value of the fruit (Nunez et al., 2007) ${ }^{[19]}$.

In India, post-harvest losses of fruits and vegetables are estimated to be 30-35 per cent which amount to losses to the extent of Rs.3000 crores (Mitbander 1990) ${ }^{[18]}$. Post-harvest losses can be minimized by adopting proper post-harvest handling practices and better understanding of biochemical control of fruit ripening. Post-harvest life of fruits and vegetables can be extended by low temperature storage, modified atmosphere packaging and by biochemical treatments. 
Mangoes are reported to ripen satisfactorily (with acceptable eating quality) between $21{ }^{\circ} \mathrm{C}$ and $24{ }^{\circ} \mathrm{C}$ (Medlicott et al., 1990) ${ }^{[13]}$. About $12-13{ }^{\circ} \mathrm{C}$ is generally considered optimum for mango storage (Kader, 1992; Medlicott et al., 1990) ${ }^{[13,17] .}$ However, for long distance transport through sea, storage of mangoes below $12-13{ }^{\circ} \mathrm{C}$ is necessary.

Chilling injury in mango has been reported to occur over a range of temperatures, differing slightly between cultivars (Cheema et al., 1939) ${ }^{[7]}$ and being further influenced by factors such as fruit maturity (Thompson, 1971; Lam and Ng, 1984) $[26,16]$ and temperature conditioning (Lam and $\mathrm{Ng}$, 1984; Thomas and Joshi, 1988) [26, 24]. Symptoms of chilling vary slightly between cultivars, although skin browning appears to be the most well-known (Snowdon, 1990) ${ }^{[22]}$. In cv. Kensington, the principal cultivar grown in Australia, chilling injury has been reported as being most prominently manifested by skin browning, poor pulp color development, and an increase in the titrable acidity of ripe fruit (Chaplin et al., 1991) [5]. In order to avoid these symptoms, storage temperatures of $13{ }^{\circ} \mathrm{C}$ and above are currently recommended for this cultivar (Hubbert and Lebger, 1988) ${ }^{[11]}$.

In view of the scanty literature on the chilling injury of mango cultivars, the present experiment was undertaken to study the effect of low temperature on prolonging the storage life.

\section{Material and Methods}

The experiment was carried out during 2014-15 at Fruit Research Station, Sangareddy, Medak. There were five treatments (varieties) replicated four times with 50 fruits per each replication. The mango cultivars used were Banganpalli, Totapari, Dashehari, Chinnarasam and Peddarasam, procured from the Fruit Research Station, Sangareddy. The experimental design followed was CRD with factorial concept. The fruits were harvested at $3 / 4^{\text {th }}$ mature stage. Data were recorded at 5 days interval. The fruits were stored at a temperature of $8^{\circ} \mathrm{C}+1{ }^{\circ} \mathrm{C}$. Physico chemical parameters like TSS, titrable acidity, ascorbic acid, reducing sugars, non reducing sugars were also estimated and subjected to statistical analysis.

\section{Results and Discussion}

The following objects were observed in different commercial mango varieties.

\section{TSS (\%)}

The highest T.S.S. (15.35) was recorded in mango cv. Peddarasam while the lowest TSS (9.08) was recorded in cv. Totapari (Table 1). The TSS in mango cv. Dashehari (12.53) was on par with that of cv. Chinnarasam (12.32). There were significant differences in TSS among different commercial varieties of mango at all the days of storage. The TSS increased significantly from $25^{\text {th }}$ day $(9.13)$ to $55^{\text {th }}$ day (13.55). Among all interactions, the highest TSS (16.75) was recorded on $55^{\text {th }}$ day with the mango cv. Peddarasam, while the lowest TSS (7.42) was recorded with the mango cv. Totapari on $25^{\text {th }}$ day of storage.

The TSS increased even in the low temperature storage indicating that the ripening process was progressing. However, the increase in TSS was more pronounced from $50^{\text {th }}$ day to $55^{\text {th }}$ day. The increase in TSS during the initial stages may be attributed to the conversion of starch and other polysaccharides into soluble forms of sugars (Satyan et al., 1992) [20] indicating that the ripening process has started. Similar results were reported by Singh et al. (2012) in mango and Jayachandran et al. (2007) ${ }^{[12]}$ in guava.

\section{Acidity (\% Citric acid)}

The lowest acidity (0.70) was recorded in mango cv. Chinnarasam and the highest acidity (1.00) was recorded in cv. Totapari (Table 2). while cv. Banganpalli (0.80) was on par with Paddarasam (0.81). The acidity decreased significantly from $25^{\text {th }}$ day (1.31) to $55^{\text {th }}$ day (0.39). Among all interactions, the lowest acidity (0.26) was recorded with the mango cv. Dashehari on $55^{\text {th }}$ day of storage whereas; the highest acidity (1.45) was recorded with cv. Totapari on both $25^{\text {th }}$ and $30^{\text {th }}$ day of storage.

In the present investigation, the acidity has decreased with the progression of the storage period. This could be attributed to the conversion of acids, into sugar (Pool et al., 1972) and utilization of organic acid during respiration (Srivastava et al., 1961) ${ }^{[23]}$. Similar decrease in acidity content of sapota fruits with increase in storage period and utilization of organic acid during respiration were reported by Kumbhar and Desai (1986). Further, among different mango varieties, Totapari has recorded highest acidity indicating slow ripening process when compared to other mango varieties. Totapari which has recorded highest acidity incidentally has lowest chilling injury index and electrolyte leakage.

\section{Brix: acid ratio}

The lowest brix acid ratio (10.04) was noticed in mango cv. Totapari. The highest (23.53) was recorded in mango cv. Peddarasam (Table 3). There were significant differences in brix acid ratio among different commercial varieties of mango at all the days of storage due to low temperature. The brix acid ratio increased significantly from $25^{\text {th }}$ day (5.61) to $55^{\text {th }}$ day (39.03). The interaction between different mango cultivars and storage period indicated that the highest brix acid ratio (47.85) was recorded with the mango cv. Totapari on $55^{\text {th }}$ day of storage.

Similar results were reported by Jayachandran et al. (2007) ${ }^{[12]}$ in guava fruits. All the treatments recorded the increased brixacid ratio with the increase in storage period which may be attributed to decrease in TSS comprised mostly of sugars, which are subjected to degradation during respiration (Amerine and Cruess, 1960) ${ }^{[1]}$.

\section{Reducing sugars (\%)}

The treated fruits were significantly influenced by low temperature with lowest reducing sugars (2.11) recorded in mango cv. Totapari (Table 4). The highest reducing sugars (2.97) were recorded in mango cv. Peddarasam. The reducing sugars increased significantly from $25^{\text {th }}$ day (1.41) to $55^{\text {th }}$ day (3.59). The interaction effect between different mango cultivars and storage periods revealed that the highest reducing sugars (3.99) were recorded with the mango cv. Dashehari on $55^{\text {th }}$ day. The lowest reducing sugars (1.11) were recorded with the mango cv. Totapari on $25^{\text {th }}$ day of storage.

In the present investigation, the reducing sugars increased throughout the storage period irrespective of the mango varieties. Hosakote et al. (2006) ${ }^{[10]}$ reported that the ripening of mango was characterized by change in biochemical constituents such as disappearance of starch, breakdown of insoluble form of polyuronides to a more soluble form, and concomitant increase in total soluble sugars but decrease in titrable acidity.

\section{Total sugars $(\%)$}

The highest total sugars (6.51) were recorded in mango cv. Peddarasam. The lowest total sugars (4.40) were recorded in 
mango cv. Totapari (Table 5). The total sugars increased significantly from $25^{\text {th }}$ day (2.32) to $55^{\text {th }}$ day (9.48). The interaction effect on total sugars among different mango cultivars and storage periods indicated that the highest total sugars (10.44) were recorded with the mango cv. Banganpalli on $55^{\text {th }}$ day of storage and the lowest total sugars (2.06) was recorded with the mango $\mathrm{cv}$. Totapari on $25^{\text {th }}$ day of storage. Upadhyay and Tripathi (1985) ${ }^{[27]}$ reported that total sugar content was augmented gradually, when stored for 6 days at room temperature. These results are in conformity with the findings of Shahjahan et al. (1994) ${ }^{[21]}$.

\section{Vitamin-C (mg/100g pulp)}

The treated fruits differed significantly with highest vitamin$\mathrm{C}$ (17.07) was recorded in mango cv Peddarasam while the lowest vitamin-C (9.67) recorded in mango cv. Banganpalli which was onpar with Chinnarasam (10.67) (Table 6). There were significant differences in vitamin-C among different commercial varieties of mango during all the days of storage. The vitamin-C decreased significantly from $25^{\text {th }}$ day (16.45) to $55^{\text {th }}$ day $(8.05)$.

Among the interactions, the highest total Vitamin-C (25.50) on $25^{\text {th }}$ day of storage was recorded with the mango cv. Peddarasam while the lowest (7.00) was recorded with cv. Banganpalli on $55^{\text {th }}$ day of storage. These findings are in agreement with those of Chaudhary and Farooqui (1969) ${ }^{[6]}$ and Tripathi (1989). Similar results were reported in guava by Jayachandran et al. (2007) ${ }^{[12]}$, Kumar and Hoda (1974) ${ }^{[15]}$ and Bhagwan and Reddy (1998) in tomato. The decline in ascorbic acid during storage may be attributed to conversion of ascorbic acid into dehydroascorbic acid.

\section{Electrolyte leakage (\%)}

The treated fruits differed significantly with lowest electrolyte leakage (13.85) recorded in mango cv. Totapari (Table 5). The highest electrolyte conductivity (24.76) was recorded in mango cv. Chinnarasam. The electrolyte leakage increased significantly from $25^{\text {th }}$ day $(17.26)$ to $55^{\text {th }}$ day (21.95).

In the present investigation, the electrolyte leakage increased with the increase in storage period irrespective of the mango variety. Further, the chilling injury also increased with progression of the storage period. Electrolyte leakage is considered as the internal measure of the chilling injury index. Due to the chilling injury, the membrane permeability increases (Waskar et al., 1999), ultimately leading to increase in leakage of electrolytes (Chanikan et al., 2012) ${ }^{[4]}$. Mango cv. Totapari and Peddarasam which are relatively resistant to the chilling injury have also recorded relatively less electrolyte leakage.

Table 1: Effect of low temperature storage on total soluble sugars $(\%)$ of commercial varieties of mango at different storagelperiods

\begin{tabular}{|c|c|c|c|c|c|c|c|c|c|c|c|c|c|}
\hline Treatments & 25 day & 30 day & 35 day & 40 day & 45 day & 50 day & 55 day & Means & 60 day & 65 day & 70 day & 75 day & 80 day \\
\hline $\mathrm{T}_{1}$ - Banganpalli & 8.75 & 10.50 & 11.00 & 11.75 & 11.75 & 12.00 & 12.25 & $11.14^{\mathrm{b}}$ & - & - & - & - & - \\
\hline $\mathrm{T}_{2}-$ Dashehari & 8.25 & 12.00 & 13.25 & 13.25 & 13.25 & 14.00 & 13.75 & $12.53^{\mathrm{c}}$ & - & - & - & - & - \\
\hline $\mathrm{T}_{3}$-Chinnarasam & 8.75 & 9.50 & 12.25 & 13.50 & 11.50 & 14.00 & 14.75 & $12.32^{\mathrm{c}}$ & - & - & - & - & - \\
\hline $\mathrm{T}_{4}-$ Peddarasam & 8.50 & 14.00 & 15.75 & 16.00 & 16.00 & 16.50 & 16.75 & $15.35^{\mathrm{d}}$ & 16.75 & 17.00 & 17.00 & - & - \\
\hline T5- Totapari & 7.42 & 8.20 & 8.50 & 9.00 & 10.00 & 10.25 & 10.25 & $9.08^{\mathrm{a}}$ & 10.50 & 12.50 & 12.50 & 13.00 & 13.80 \\
\hline Means & $9.13^{\mathrm{a}}$ & $10.84^{\mathrm{b}}$ & $12.15^{\mathrm{c}}$ & $12.70^{\mathrm{c}}$ & $12.90^{\mathrm{c}}$ & $13.35^{\mathrm{d}}$ & $13.55^{\mathrm{d}}$ & - & & & & & \\
\hline & \multicolumn{2}{|c|}{ F-Test } & \multicolumn{2}{|c|}{ SEM } & \multicolumn{2}{|c|}{ CD } & & & & & & & \\
\hline For Treatments & \multicolumn{2}{|c|}{$* *$} & \multicolumn{2}{|c|}{0.164} & \multicolumn{2}{|c|}{0.460} & & & & & & & \\
\hline For Days & \multicolumn{2}{|c|}{$* *$} & \multicolumn{2}{|c|}{0.194} & \multicolumn{2}{|c|}{0.544} & & & & & & & \\
\hline For T X D & \multicolumn{2}{|c|}{$* *$} & \multicolumn{2}{|c|}{0.434} & \multicolumn{2}{|c|}{1.218} & & & & & & & \\
\hline
\end{tabular}

Table 2: Effects of low temperature storage on acidity (\% citric acid) of commercial varieties of mango at different storage periods

\begin{tabular}{|c|c|c|c|c|c|c|c|c|c|c|c|c|c|}
\hline Treatments & 25 day & 30 day & 35 day & 40 day & 45 day & 50 day & 55 day & Means & 60 day & 65 day & 70 day & 75 day & 80 day \\
\hline $\mathrm{T}_{1}$ - Banganpalli & 1.36 & 1.36 & 0.76 & 0.74 & 0.61 & 0.44 & 0.34 & $0.80^{\mathrm{c}}$ & - & - & - & - & - \\
\hline $\mathrm{T}_{2}-$ Dashehari & 1.31 & 1.31 & 0.74 & 0.72 & 0.60 & 0.43 & 0.26 & $0.76^{\mathrm{b}}$ & - & - & - & - & - \\
\hline $\mathrm{T}_{3}$ - Chinnarasam & 1.04 & 1.04 & 0.75 & 0.72 & 0.58 & 0.42 & 0.32 & $0.70^{\mathrm{a}}$ & - & - & - & - & - \\
\hline $\mathrm{T}_{4}-$ Peddarasam & 1.39 & 1.39 & 0.73 & 0.71 & 0.66 & 0.45 & 0.35 & $0.81^{\mathrm{c}}$ & 0.27 & 0.26 & 0.23 & - & - \\
\hline $\mathrm{T}_{5}$ - Totapari & 1.45 & 1.45 & 0.94 & 0.93 & 0.83 & 0.76 & 0.67 & $1.00^{\mathrm{d}}$ & 0.63 & 0.85 & 0.82 & 0.69 & 0.51 \\
\hline Means & $1.31^{\mathrm{a}}$ & $1.31^{\mathrm{a}}$ & $0.78^{\mathrm{b}}$ & $0.76^{\mathrm{b}}$ & $0.65^{\mathrm{c}}$ & $0.50^{\mathrm{d}}$ & $0.39^{\mathrm{e}}$ & & & & & & \\
\hline & \multicolumn{2}{|c|}{ F-Test } & \multicolumn{2}{|c|}{ SEM } & \multicolumn{2}{|c|}{ CD } & & & & & & & \\
\hline For Treatments & \multicolumn{2}{|c|}{$* *$} & \multicolumn{2}{|c|}{0.013} & \multicolumn{2}{|c|}{0.038} & & & & & & & \\
\hline For Days & \multicolumn{2}{|c|}{$* *$} & \multicolumn{2}{|c|}{0.016} & \multicolumn{2}{|c|}{0.045} & & & & & & & \\
\hline For T X D & \multicolumn{2}{|c|}{$* *$} & \multicolumn{2}{|c|}{0.036} & \multicolumn{2}{|c|}{0.103} & & & & & & & \\
\hline
\end{tabular}

Table 3: Effects of low temperature storage on Brix to acid ratio of commercial varieties of mango

\begin{tabular}{|c|c|c|c|c|c|c|c|c|c|c|c|c|c|}
\hline Treatments & 25 day & 30 day & 35 day & 40 day & 45 day & 50 day & 55 day & Means & 60 day & 65 day & 70 day & 75 day & 80 day \\
\hline $\mathrm{T}_{1}$ - Banganpalli & 6.43 & 7.72 & 14.47 & 15.87 & 19.26 & 27.27 & 36.02 & $18.15^{\mathrm{b}}$ & - & - & - & - & - \\
\hline $\mathrm{T}_{2}-$ Dashehari & 6.29 & 9.16 & 17.90 & 18.40 & 22.08 & 32.55 & 52.88 & $22.75^{\mathrm{d}}$ & - & - & - & - & - \\
\hline $\mathrm{T}_{3}$-Chinnarasam & 8.41 & 9.13 & 16.33 & 18.75 & 19.82 & 33.33 & 46.09 & $21.69^{c}$ & - & - & - & - & - \\
\hline $\mathrm{T}_{4}-$ Peddarasam & 1.79 & 10.07 & 21.57 & 22.53 & 24.24 & 36.66 & 47.85 & $23.53^{\mathrm{e}}$ & 62.03 & 65.38 & 73.91 & - & - \\
\hline $\mathrm{T}_{5}$ - Totapari & 5.11 & 5.65 & 9.04 & 9.67 & 12.04 & 13.48 & 15.29 & $10.04^{\mathrm{a}}$ & 16.66 & 14.70 & 15.24 & 18.84 & 27.05 \\
\hline Means & $5.61^{\mathrm{a}}$ & $8.34^{\mathrm{b}}$ & $15.86^{\mathrm{c}}$ & $17.04^{\mathrm{d}}$ & $19.49^{\mathrm{e}}$ & $28.66^{\mathrm{f}}$ & $39.63^{\mathrm{g}}$ & & & & & & \\
\hline & \multicolumn{2}{|c|}{ F-Test } & \multicolumn{2}{|c|}{ SEM } & \multicolumn{2}{|c|}{ CD } & & & & & & & \\
\hline For Treatments & \multicolumn{2}{|c|}{$* *$} & \multicolumn{2}{|c|}{0.133} & \multicolumn{2}{|c|}{0.388} & & & & & & & \\
\hline For Days & \multicolumn{2}{|c|}{$* *$} & \multicolumn{2}{|c|}{0.163} & \multicolumn{2}{|c|}{0.455} & & & & & & & \\
\hline For T X D & \multicolumn{2}{|c|}{$* *$} & \multicolumn{2}{|c|}{0.368} & \multicolumn{2}{|c|}{1.074} & & & & & & & \\
\hline
\end{tabular}


Table 4: Effects of low temperature storage on reducing sugars (\%) of commercial varieties of mango at different storage periods

\begin{tabular}{|c|c|c|c|c|c|c|c|c|c|c|c|c|c|}
\hline Treatments & 25 day & 30 day & 35 day & 40 day & 45 day & 50 day & 55 day & Means & 60 day & 65 day & 70 day & 75 day & 80 day \\
\hline $\mathrm{T}_{1}$ - Banganpalli & 1.24 & 1.84 & 2.02 & 2.79 & 2.72 & 2.86 & 3.86 & $2.48^{\mathrm{b}}$ & - & - & - & - & - \\
\hline $\mathrm{T}_{2}-$ Dashehari & 1.33 & 1.88 & 2.54 & 2.82 & 3.39 & 3.44 & 3.99 & $2.77^{\mathrm{c}}$ & - & - & - & - & - \\
\hline $\mathrm{T}_{3}$-Chinnarasam & 1.56 & 1.88 & 2.26 & 2.79 & 3.32 & 3.42 & 3.88 & $2.73^{\mathrm{c}}$ & - & - & - & - & - \\
\hline $\mathrm{T}_{4}-$ Peddarasam & 1.80 & 1.91 & 2.73 & 3.37 & 3.70 & 3.81 & 3.49 & $2.97^{\mathrm{d}}$ & 3.66 & 3.71 & 3.89 & - & - \\
\hline $\mathrm{T}_{5}$ - Totapari & 1.11 & 1.38 & 1.92 & 2.38 & 2.60 & 2.68 & 3.73 & $2.11^{\mathrm{a}}$ & 2.14 & 2.50 & 2.52 & 2.60 & 2.70 \\
\hline Means & $1.41^{\mathrm{a}}$ & $1.78^{\mathrm{b}}$ & $2.30^{\mathrm{c}}$ & $2.83^{\mathrm{d}}$ & $3.14^{\mathrm{e}}$ & $3.24^{\mathrm{e}}$ & $3.59^{\mathrm{f}}$ & & & & & & \\
\hline & \multicolumn{2}{|c|}{ F-Test } & \multicolumn{2}{|c|}{ SEM } & \multicolumn{2}{|c|}{ CD } & & & & & & & \\
\hline For Treatments & \multicolumn{2}{|c|}{$* *$} & \multicolumn{2}{|c|}{0.041} & \multicolumn{2}{|c|}{0.115} & & & & & & & \\
\hline For Days & \multicolumn{2}{|c|}{$* *$} & \multicolumn{2}{|c|}{0.048} & \multicolumn{2}{|c|}{0.137} & & & & & & & \\
\hline For T X D & \multicolumn{2}{|c|}{$* *$} & \multicolumn{2}{|c|}{0.109} & \multicolumn{2}{|c|}{0.306} & & & & & & & \\
\hline
\end{tabular}

Table 5: Effects of low temperature storage on total sugars (\%) of commercial varieties of mango at different storage periods.

\begin{tabular}{|c|c|c|c|c|c|c|c|c|c|c|c|c|c|}
\hline Treatments & 25 day & 30 day & 35 day & 40 day & 45 day & 50 day & 55 day & Means & 60 day & 65 day & 70 day & 75 day & 80 day \\
\hline $\mathrm{T}_{1}$ - Banganpalli & 2.29 & 2.50 & 4.58 & 6.75 & 8.37 & 9.34 & 10.44 & $6.32^{\mathrm{b}}$ & - & - & - & - & - \\
\hline $\mathrm{T}_{2}-$ Dashehari & 2.33 & 2.45 & 4.26 & 6.64 & 8.76 & 9.46 & 10.25 & $6.31^{\mathrm{b}}$ & - & - & - & - & - \\
\hline $\mathrm{T}_{3}$-Chinnarasam & 2.26 & 2.44 & 4.83 & 6.58 & 8.69 & 9.50 & 10.32 & $6.37^{\mathrm{b}}$ & - & - & - & - & - \\
\hline $\mathrm{T}_{4}-$ Peddarasam & 2.68 & 2.85 & 4.81 & 6.91 & 8.70 & 9.60 & 10.30 & $6.51^{\mathrm{c}}$ & 10.48 & 10.68 & 10.86 & - & - \\
\hline $\mathrm{T}_{5}$-Totapari & 2.06 & 3.07 & 3.02 & 4.65 & 5.29 & 6.37 & 6.37 & $4.40^{\mathrm{a}}$ & 6.92 & 7.05 & 7.15 & 8.38 & 8.50 \\
\hline Means & $2.32^{\mathrm{a}}$ & $2.66^{\mathrm{b}}$ & $4.30^{\mathrm{c}}$ & $6.30^{\mathrm{d}}$ & $7.96^{\mathrm{e}}$ & $8.86^{\mathrm{f}}$ & $9.48^{\mathrm{g}}$ & & & & & & \\
\hline & \multicolumn{2}{|c|}{ F-Test } & \multicolumn{2}{|c|}{ SEM } & \multicolumn{2}{|c|}{ CD } & & & & & & & \\
\hline For Treatments & \multicolumn{2}{|c|}{$* *$} & \multicolumn{2}{|c|}{0.080} & \multicolumn{2}{|c|}{0.226} & & & & & & & \\
\hline For Days & \multicolumn{2}{|c|}{$* *$} & \multicolumn{2}{|c|}{0.095} & \multicolumn{2}{|c|}{0.267} & & & & & & & \\
\hline For T X D & \multicolumn{2}{|c|}{$* *$} & \multicolumn{2}{|c|}{0.213} & \multicolumn{2}{|c|}{0.598} & & & & & & & \\
\hline
\end{tabular}

Table 6: Effects of low temperature storage on vitamin C (mg/100 g pulp) of commercial varieties of mango

\begin{tabular}{|c|c|c|c|c|c|c|c|c|c|c|c|c|c|}
\hline Treatments & 25 day & 30 day & 35 day & 40 day & 45 day & 50 day & 55 day & Means & 60 day & 65 day & 70 day & 75 day & 80 day \\
\hline $\mathrm{T}_{1}$ - Banganpalli & 14.00 & 11.75 & 10.50 & 9.00 & 8.25 & 7.25 & 7.00 & $9.67^{\mathrm{a}}$ & - & - & - & - & - \\
\hline $\mathrm{T}_{2}$ - Dashehari & 13.00 & 13.00 & 12.00 & 10.75 & 10.25 & 10.25 & 7.25 & $10.92^{\mathrm{b}}$ & - & - & - & - & - \\
\hline $\mathrm{T}_{3}$-Chinnarasam & 14.00 & 12.25 & 11.50 & 10.50 & 9.50 & 9.00 & 8.00 & $10.67^{\mathrm{a}}$ & - & - & - & - & - \\
\hline $\mathrm{T}_{4}$ - Peddarasam & 25.50 & 23.00 & 21.00 & 19.50 & 11.50 & 9.75 & 9.25 & $17.07^{\mathrm{d}}$ & 7.75 & 7.00 & 7.00 & - & - \\
\hline $\mathrm{T}_{5}$ - Totapari & 15.75 & 15.50 & 15.00 & 11.25 & 10.25 & 9.75 & 8.75 & $12.32^{\mathrm{c}}$ & 7.25 & 7.75 & 7.75 & 6.75 & 6.25 \\
\hline Means & $16.45^{\mathrm{e}}$ & $15.10^{\mathrm{d}}$ & $14.00^{\mathrm{d}}$ & $12.20^{\mathrm{c}}$ & $9.95^{\mathrm{b}}$ & $9.20^{\mathrm{a}}$ & $8.05^{\mathrm{a}}$ & & & & & & \\
\hline & \multicolumn{2}{|c|}{ F-Test } & \multicolumn{2}{|c|}{ SEM } & \multicolumn{2}{|c|}{$\mathrm{CD}$} & & & & & & & \\
\hline For Treatments & \multicolumn{2}{|c|}{$* *$} & \multicolumn{2}{|c|}{0.414} & \multicolumn{2}{|c|}{1.162} & & & & & & & \\
\hline For Days & \multicolumn{2}{|c|}{$* *$} & \multicolumn{2}{|c|}{0.490} & \multicolumn{2}{|c|}{1.375} & & & & & & & \\
\hline For T X D & \multicolumn{2}{|c|}{$* *$} & \multicolumn{2}{|c|}{1.096} & \multicolumn{2}{|c|}{3.076} & & & & & & & \\
\hline
\end{tabular}

Table 7: Effects of low temperature storage on electrolyte leakage (\%) of commercial verities of mango at different storage periods

\begin{tabular}{|c|c|c|c|c|c|c|c|c|c|c|c|c|c|}
\hline \multirow{2}{*}{ Treatments } & \multicolumn{13}{|c|}{ Days of storage } \\
\hline & 25 & 30 & 35 & 40 & 45 & 50 & 55 & Means & 60 & 65 & 70 & 75 & 80 \\
\hline $\mathrm{T}_{1}$ - Banganpalli & 14.25 & 15.00 & 15.50 & 16.00 & 16.25 & 17.75 & 19.00 & $16.25^{\mathrm{a}}$ & - & - & - & - & - \\
\hline $\mathrm{T}_{2}-$ Dashehari & 21.82 & 22.75 & 24.00 & 25.00 & 26.00 & 26.75 & 27.00 & $23.90^{\mathrm{d}}$ & - & - & - & - & - \\
\hline $\mathrm{T}_{3}$-Chinnarasam & 21.50 & 22.25 & 22.50 & 23.52 & 24.25 & 25.50 & 26.50 & $24.76^{\mathrm{e}}$ & - & - & - & - & - \\
\hline $\mathrm{T}_{4}-$ Peddarasam & 17.00 & 17.75 & 18.00 & 19.00 & 19.75 & 20.25 & 20.75 & $18.92^{\mathrm{a}}$ & 21.50 & 22.00 & 23.25 & - & - \\
\hline T5-Totapari & 11.75 & 12.25 & 13.00 & 13.50 & 14.25 & 15.75 & 16.50 & $13.85^{\mathrm{a}}$ & 18.75 & 19.25 & 20.50 & 21.25 & 22.25 \\
\hline Means & $17.26^{\mathrm{a}}$ & $18.00^{\mathrm{a}}$ & $18.60^{\mathrm{a}}$ & $19.35^{\mathrm{b}}$ & $20.10 \mathrm{~b}$ & $21.20^{\mathrm{b}}$ & $21.95^{\mathrm{c}}$ & & & & & & \\
\hline & F-Test & SEM & $\mathrm{CD}$ & & & & & & & & & & \\
\hline For Treatments $(\mathrm{T})$ & $* *$ & 0.275 & 0.772 & & & & & & & & & & \\
\hline For Days (D) & $* *$ & 0.325 & 0.913 & & & & & & & & & & \\
\hline For T X D & NS & 0.728 & - & & & & & & & & & & \\
\hline
\end{tabular}

\section{Conclusion}

Significantly lowest chilling injury was recorded in mango cv Totapari followed by Peddarasam. Significantly highest chilling injury was recorded in the mango cv Chinnarasam. In the varieties where chilling injury was highest, significantly maximum electrolyte leakage was recorded. Irrespective of the variety, storage at low temperature has significantly delayed the ripening process. The various physico chemical parameters indicated reduced chilling injury symptoms in mango cv. Totapari.

\section{References}

1. Amerine MA, Cruess WV. The technology of wine making west port. AVI publishing company Inc. Connecticut 1960.

2. Bhagwan A, Reddy YN, Rao PV. Post harvest application of polyamines to improve the shelf life of tomato fruit. Indian Journal of Horticulture 1998;57(2):133-138.

3. Biale JB. Synthetic and degradative process in fruit ripening in Post harvest biology and handling of fruits and vegetables Eds: Haard N F and Salunkhe D K. the AVI publishing Co., Westport, Connecticut, USA 1975.

4. Chanikan J, Jamnong U, Danai B, Bualuang F, Kobkiat S. Reduction of Chilling Injury of 'Nam Dok Mai No. 4' Mango Fruit by Treatments with Salicylic Acid and 
Methyl Jasmonate. Journal of Agricultural Science 2012;4(10):126-136.

5. Chaplin GR, Cole SP, Landrin M, Nuevo PA, Lam PF, Graham D. Chilling injury and storage of mango (Mangifera indica L.) held under low temperature. Acta Horticulturae 1991;291:461-471.

6. Chaudhary TM, Farooqui MAR. The post harvest chemical changes during the ripening of mango fruits. West Pakistan Journal of Agricultural Research 1969;7(3):78-96.

7. Cheema GS, Karmakar DV, Joshi BM. Investigations on the cold storage of mangoes. Agricultural Science 1950;20:259-262.

8. Haines W. The world of mango situation-a market perspective. Acta Horticulture 1991;291:1-11.

9. Hatton TT. Reeder WF, Campbell CW. Ripening and storage of Florida mangoes. USDA Mktg. Res. Report No.275 1965.

10. Hosakote MY, Tyakal NP, Rudrapatnam NT. Mango ripening: changes in cell wall constituents in relation to textural softening. Journal. Science for Food Agriculture 2006;86:713-721.

11. Hubbert CA, Ledger SN. Manoes; post-harvest handling system. Queensl. Department Primary Ind, Farm-note 1988.

12. Jayachandran KS, Srihari D, Reddy YN. Post harvest application of selected antioxidants to improve the shelf life of guava fruit. Acta-Horticulturae 2007;735:627-632.

13. Kader. Reduction of chilling injury in 'Tommy Atkins'mangoes during ripening 1992.

14. Kosiyacinda S, Young RE. Chilling sensitivity of avocado at different sages of the respiratory climacteric. Journal of American Society for Horticultural Science 1976;101:665-669.

15. Kumar R, Hoda NN. Fixation of maturity standards of guava (Psidium guajava L.). Indian Journal of Horticulture 1974;31:140-144.

16. Lam $\mathrm{PF}, \mathrm{Ng} \mathrm{KH}$. Influence of temperature adaption and physiological stage on the storage of 'Harimanis' mangoes. Proc. First Aust. Mango Res. Work sh., Nov. 1984, Cairns, Queensl 1984, 274-277.

17. Medlicott AP, Sigrist JM, Sy O. Ripening of mangoes following low temperature storage. J Am. Soc 1990.

18. Mitbander VB. Thrust industry reaches dead end. Indian Food Packer 1990;44:3.

19. Nunez MC, Emond JP, Brecht JK, Dea S, Proulx E. Quality curves for mango fruit (cv. Tommy Atkins and Palmer) stored at chilling and nonchilling temperature. Journal of food quality 2007;30:104-120.

20. Satyan S, Scott KJ, Graham D. Storage of banana bunches in sealed polyethylene tubes. Journal of Horticulture Science 1992;67(2):51-53.

21. Shahjahan MS, Sheel MA. Zaman MA, Sakur MA. Optimization of harvesting maturities for major mango cultivars in Bangladesh. Bangladesh Journal Science Research 1994;12(22):209-215.

22. Snowdon AL. A colour atlas of post-harvest diseases and disorders of fruit and vegetables, volume 1: general introduction and fruits, Wolfe Scientific Ltd. London, 1990, 302.

23. Srivastava HC, Kapur NS, Pala VB. Storage behavior of skin coated guavas under modified atmosphere. Food Science 1961;11:244-248.

24. Thomas P, Joshi MR. Reduction of chilling injury in ripe Alphonso mango fruit in cold storage by temperature conditioning. International Journal Food Science Technology 1988;23:447-455.

25. Thomas $\mathrm{P}$, Oke MS. Improvement in quality an storage of 'Alphonso' mango by cold adaption. Science Horticulture 1983;19:257-262.

26. Thompson AK. The storage of mango fruits. Trop. Agric. (Trinidad) 1971;48:63-70.

27. Upadhyay NP, Tripathi BM. Post-harvest changes during storage and ripening of Gaurjeet mango (Mangifera indica L.) fruits. Progressive Horticulture 1985;17(1):2527. 